\title{
The Evaluation of Industrial Work Practices Program in Accounting Students at Vocational High School 50, Jakarta
}

\section{Fandy Septia Anggriawan}

Informatics Education Studies Program, Electrical Engineering, Faculty of Engineering, University of Jakarta, Rawamangun, Indonesia

\section{Abstract}

Industrial Work Practice Program (Prakerin) is expected to be a means for students to become professional workers who are ready to find a way out of the problems faced in the future. However, the conditions and facts on the ground today are not as expected. This study aims to evaluate how the context, input, process, and results in the industrial work practice program in the Department of Accounting at Vocational High School 50 Jakarta. The type of research is evaluation research with CIPP

Corresponding Author: Fandy Septia Anggriawan fandyseptia@unj.ac.id

Received: 11 January 2019 Accepted: 14 February 2019 Published: 25 March 2019

Publishing services provided by Knowledge E

\section{(c) Fandy Septia}

Anggriawan. This article is distributed under the terms of the Creative Commons

Attribution License, which permits unrestricted use and redistribution provided that the original author and source are credited.

Selection and Peer-review under the responsibility of the 3rd ICTVET 2018 Conference Committee.

\section{G OPEN ACCESS} evaluation model (Context, Input, Process, Product). The method used is quantitative methods. Quantitative data were collected through questionnaires distributed to 31 respondents. The results of the study conclude that the program of industrial work practices in the Department of Accounting at Vocational High School 50 Jakarta is in the good category, but still needs improvement in the input and process components.

Keywords: Industrial Work Practice Program, Evaluation, Vocational High School

\section{Introduction}

The era of globalization has had a significant impact on the lives of Indonesian people. The impact of the globalization era, among others, is the existence of a form of cooperation in the business world and another impact is the existence of competition in the increasingly tight work world. To deal with the era of globalization, Indonesia needs a workforce that has high professional expertise in the face of current and future global economic developments. One place to form professional expertise is Vocational High School.

Vocational High Schools or SMK are part of the National Education System, which has an important role in preparing and developing Human Resources. UUSPN No. 20, 2003 article 15 states that vocational secondary education aims to prepare students especially to work in certain fields. This goal can be explained again by Depdiknas 
(2003). Vocational graduates must have competencies in accordance with the expertise program chosen and ready to compete in the world of work. Based on the objectives of vocational education, the learning program in vocational high schools is one of them is to implement a dual system program. Dual system education in vocational schools is applied as industrial work practices or called apprenticeship. In the Ministry of National Education Vocational Curriculum (2005) stated: Prakerin is a pattern of administering education and training jointly managed between Vocational Schools and industries as partner institutions (IP), starting from the planning, implementation to evaluation and certification stages which are a unified program using various alternative forms implementation, such as day release, block release, and others.

However, it is considered necessary to carry out an evaluation on the Industrial Work Practices Program (Prakerin) of Students, in this study conducted at the Accounting Department at SMK Negeri 50 Jakarta, evaluation of the Prakerin program was needed to look deeply into each component of the Prakerin program with the CIPP evaluation model (Context, Input, Process, and Product). Evaluation is the process of understanding or giving meaning, obtaining and communicating information for the guidance of decision-making parties (Wakhinuddin, 2009: 44). According to Stufflebeam in Daryanto (2007: 1), evaluation is the process of describing, obtaining, and presenting information that is useful for assessing alternative decisions.

\section{Objects and Research Methods}

\subsection{Research object}

The object of this study was the XII grade students of the Vocational High School 50 Jakarta Accounting Department who had completed the internship activities, Vocational High School 50 Jakarta is located at Jl. Cipinang Muara 1 Cipinang, Jatinegara subdistrict, East Jakarta.

\subsection{Types of research}

Type of this research is evaluation research with the Context, Input, Process, Product model (CIPP). Evaluation is done to find out the implementation of program activities, which in the final goal is to determine the next policy. In this case the researcher evaluates the Industrial Work Practice program of students with an Accounting expertise program at vocational High School 50 Jakarta which is reviewed in context, (b) input, (c) 
process, (d) product. The method used in this study is a quantitative method obtained through interviews, documentation, and observation to the subject of the study.

\subsection{Research stages}

The following are the stages in this research:

1. Collecting data

In this stage the quantitative data collection techniques used in this study are questionnaires. This study uses a closed questionnaire, where communication is carried out indirectly. Respondents are asked to choose one answer that matches their characteristics by encircling one of the answers according to respondents according to the real conditions.

The questionnaire (questionnaire) is compiled based on the CIPP evaluation model like context, input, process, and product using a Likert scale with four alternative answers.

2. Instrument testing

Instruments that have been compiled before being used first are tested to find out valid and invalid item items, then to find out the reliability level of the questionnaire that will be used as an instrument in the study.

3. Quantitative data analysis

Based on the research method conducted, the data analysis technique that is conducted is by quantitative methods.

\subsection{Results and study}

In this section, the description of the data and the level of achievement of the respondents in each component of the Industrial Work Practice Evaluation study program majoring in Accounting at vocational high school 50 Jakarta with the CIPP model consisting of Context, Input, Process, and Product variables. The following are the results of the respondents' achievement in each variable.

\subsubsection{Context variable}

The average acquisition value of the four indicators related to the component context of the industrial work practice program, namely the Industrial Worker Environment, the 
Opportunity in the Work Practice, the Requirement for Industrial Work Practice, and the Objective of the Apprenticeship Program obtained an average score of 4.13 at a percentage of $82.7 \%$ with the good assessment category. And then, it can be concluded that the context component is good and still needs to get more attention so that in the future it can increase very well.

\subsubsection{Input variable}

The average acquisition value of the seven indicators related to the input component of the industrial work practice program that is students of the Prakerin Participants, Supervising Teachers \& Instructors, Curricula, Prakerin Schedules, Facilities and Infrastructure, Costs, and Program Relevance obtained an average value of 3.74 in percentage $74.9 \%$ with enough rating categories. And then it can be concluded that the input component is quite good and still needs more attention so that in the future it can improve for the better.

\subsubsection{Process variable}

The average acquisition value of the four indicators related to the component Program process Industrial work practices namely Preparation of industrial work practices, Implementation of industrial work practices, Monitoring Implementation of industrial work practices, and Obstacles to Implementation Industrial work practices obtained an average value of 3.25 in percentage $65 \%$ with enough assessment categories. And then It can be concluded that the Process component needs to get more attention by the expertise Program of Accounting at vocational high school 50 Jakarta because it is still in the sufficient category.

\subsubsection{Product variable}

The average value of the two indicators related to the components of the program results Industrial work practices namely Achievement Industrial Work Practice Objectives and Long- Term Impacts Industrial work practices obtained an average value of 4.19 at a percentage of $83.7 \%$ with a good assessment category. And then It can be concluded that this apprenticeship program provides results for students expertise Program in Accounting at vocational high school 50 Jakarta. 


\section{Conclusion}

Based on the results of the research conducted, it can be concluded that the industrial work practice program in the Accounting expertise program in vocational high school 50 Jakarta is in the good category, but still needs improvement and improvement in the input and process components.

\section{References}

[1] Daryanto. 2007. Evaluasi Pendidikan. Jakarta: Rineka Cipta.

[2] akhinuddin. 2009. Evaluasi Program. Padang: UNP Press. 